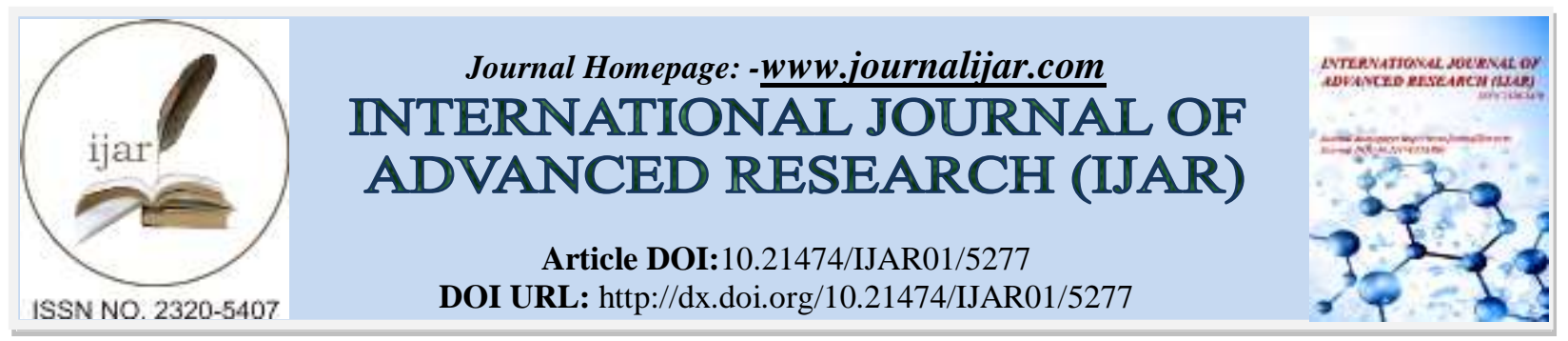

RESEARCH ARTICLE

\title{
EVALUATION OF PROXIMATE PRINCIPLES AND ANTIOXIDANT ACTIVITY OF MORINGA OLEIFERA LAM. (DRUM STICK TREE) IN KERALA.
}

\author{
Aju B.Y ${ }^{1}$, Rajalakshmi. $\mathbf{R}^{1}$ and Mini.S ${ }^{2}$. \\ 1. Department of Botany, University of Kerala, Kariavattom, Thiruvananthapuram. \\ 2. Department of Biochemistry, University of Kerala, Kariavattom, Thiruvananthapuram.
}

\section{Manuscript Info}

Manuscript History

Received: 25 June 2017

Final Accepted: 27 July 2017

Published: August 2017

Keywords:-

Moringaoleifera, Proximate principles,

Antioxidant potential.

\begin{abstract}
Moringa oleifera is the most widely cultivated species of the genus Moringa, which is the only genus in the family Moringaceae. It is commonly referred to as 'drumstick tree' or 'horse radish tree'. The present study investigates the nutritional and antioxidant potential of the plant. The proximate principles analyzed were carbohydrate, protein, starch, total sugar, reducing and non reducing sugar, total lipid, crude fat, fatty acid, total free amino acids, vitamins (A.C,E,B1,B2,B3) and minerals $(\mathrm{Mg}, \mathrm{Fe}, \mathrm{Mn}, \mathrm{Zn}, \mathrm{Cu}, \mathrm{Ag}, \mathrm{Ni}, \mathrm{B}, \mathrm{Co}, \mathrm{Li})$ using standard protocols. The anti nutritional factors oxalate and tannin was also estimated. The antioxidant potential of the plant was determined using DPPH radical scavenging activity, reducing power, total antioxidant activity,nitric oxide radical scavenging activity, hydrogen peroxide scavenging activity, hydroxyl radical scavenging activity and superoxide radical scavenging activity. The result reveals that Moringa oleifera is highly nutritious and have strong antioxidant potential.
\end{abstract}

Copy Right, IJAR, 2017,. All rights reserved.

\section{Introduction:-}

Nutraceuticals are products derived from food sources that are purported to provide extra health benefits, in addition to the basic nutritional value found in foods. Plant based nutraceuticals are plant products with nutritional and medicinal values. In other words, these are food with pharmaceutical properties (Health Canada, 2013).Moringa oleifera is the most widely cultivated species of the genus Moringa, which is the only genus in the family Moringaceae and is native to India. Moringa oleifera is a single source of all the nutrients and has several traditional and therapeutic uses. It is being used as a nutritional supplement in many parts of the world. Despite the nutraceutical importance, the plant has different pharmacological activities. Moringa tree is used in treating malnutrition, especially among infants and mothers. Almost all the parts of this plant have been used for various ailments in the indigenous medicine of South Asia, including the treatment of inflammation and infectious diseases along with cardiovascular, gastro intestinal, haematological and hepato renal disorders (The wealth of India, 1962; Singh and Kumar,1999; Siddhuraju and becker,2003).

Edible plant parts with antioxidant properties are considered as plant based antioxidant nutraceuticals. Only those parts of plants that are consumed normally as human food in any parts of the world are to be used in the preparation of nutritional medicine (dietary formulation). The present study deals with the nutritional, anti nutritional and anti oxidant potential of leaves of the plant. 


\section{Materials and Methods:-}

\section{Plant material:-}

Moringa oleifera leaves were collected from Trivandrum and authenticated by Dr. G. Valsaladevi, Department of Botany, University of Kerala.

\section{Nutritional analysis:-}

The fresh leaves were collected, washed, dried and then crushed in a mortar and pestle and were subjected to various biochemical analyses. The proximate principles total carbohydrate, starch, protein, total reducing and non reducing sugar (Sadasivam and Manickam,1996), total sugar (Hodge and Hofreiter 1962), total lipid (Bligh and dyer 1959),vitamins (Vit A,B1,B2,B3,C,E) (AOAC,1994;Okwu and Josiah ,2006), total free amino acids (Moore and stein,1948), crude fat, fatty acid, anti nutritional factors oxalate (AOAC,1990) and tannin (Schanderl,1970) were determined using standard protocols. The inductively coupled mass spectrometry (ICP-MS) system Thermo Scientific ICAP Qc was used for the mineral (Mg, Fe, Mn, Zn, Cu, Ag, Ni, Co, Li) analysis.

\section{Antioxidant analysis:-}

Dried leaf powder (5g) of Moringa oleifera was extracted with methanol, hydro alcohol (1:1) and water using soxhlet apparatus. Each extract obtained was filtered using Whatman No.1 filter paper, dried to a semisolid mass and the yield of each extract was recorded. These extracts were screened for their antioxidant potential using various antioxidant assays. Antioxidant activity was determined using standard protocols of total antioxidant activity (Prieto et al., 1999), DPPH radical scavenging activity (Blois,1958), reducing power (Oyizu,1986), nitric oxide radical scavenging activity (Ilavarasan et al., 2005), hydrogen peroxide scavenging activity (Ruch et al .,1989), hydroxyl radical scavenging activity (Halliwell et al., 1987),superoxide radical scavenging activity (Fontana et al., 2001).

\section{Results and Discussion:-}

\section{Nutritional analysis:-}

The results of nutritional analysis showed that the Moringa oleifera leaves were rich in various nutrients (Table 1) such as carbohydrates, proteins, free amino acids and sugars. The vitamin analysis revealed that the leaves contained appreciable quantity of vitamins. The anti nutritional factors oxalate and tannin is present in very minute quantity. Moringa oleifera leaves are highly nutritious and have the ability to abolish malnutrition. Mineral analysis showed that Moringa oleifera is rich in various mineral elements (Table 2). $\mathrm{Mg}$ and $\mathrm{Fe}$ were found in higher amounts than all the other elements checked.

Table 1:-Nutritional status of Moringa oleifera leaves.

\begin{tabular}{|l|l|}
\hline Nutrients & Moringa oleifera $(\mathbf{1 0 0 g})$ \\
\hline Carbohydrate $(\mathrm{g})$ & $38.4 \pm 0.90$ \\
\hline Starch $(\mathrm{mg})$ & $12.042 \pm 0.02$ \\
\hline Total sugar $(\mathrm{mg})$ & $0.8 \pm 0.05$ \\
\hline Total non reducing sugar(mg) & $0.52 \pm 0.02$ \\
\hline Total reducing sugar $(\mathrm{mg})$ & $0.28 \pm 0.03$ \\
\hline Protein $(\mathrm{g})$ & $27.1 \pm 0.725$ \\
\hline Total lipid $(\mathrm{g})$ & $1.37 \quad \pm 0.04$ \\
\hline Crude fat $(\mathrm{mg})$ & $5.04 \pm 0.03$ \\
\hline Fatty acids $(\mathrm{mg})$ & $4.03 \pm 0.3$ \\
\hline Total free amino acids $(\mathrm{mg})$ & $118.2 \pm 0.7$ \\
\hline Vitamin A (mg) & $13.48 \pm 0.51$ \\
\hline Vitamin C(mg) & $245.13 \pm 0.46$ \\
\hline Vitamin E(mg) & $16.80 \pm 0.24$ \\
\hline Vitamin B1(mg) & $0.05 \pm 0.28$ \\
\hline Vitamin B2(mg) & $0.8 \pm 0.25$ \\
\hline Vitamin B3(mg) & $220 \pm 0.042$ \\
\hline Oxalate (mg) & $0.462 \pm 0.03$ \\
\hline Tannin (mg) & $0.30 \pm 0.03$ \\
\hline
\end{tabular}

*Data is presented as the mean \pm standard deviation. 
Table 2:-Mineral profiling in Moringa oleifera.

\begin{tabular}{|l|l|l|}
\hline S.No & Minerals & (mg/Kg) \\
\hline 1 & $\mathrm{Mg}$ & 3689 \\
\hline 2 & $\mathrm{Fe}$ & 360.4 \\
\hline 3 & $\mathrm{Mn}$ & 31.3 \\
\hline 4 & $\mathrm{Zn}$ & 24.8 \\
\hline 5 & $\mathrm{Cu}$ & 43.1 \\
\hline 6 & $\mathrm{Ag}$ & 1.3 \\
\hline 7 & $\mathrm{Ni}$ & 39.2 \\
\hline 8 & $\mathrm{Co}$ & 1.2 \\
\hline 9 & $\mathrm{Li}$ & 1.6 \\
\hline
\end{tabular}

\section{Antioxidant analysis:-}

Total antioxidant capacity:-

The total antioxidant capacity (TAC) was based on the reduction of Mo (VI) to Mo (V) by the extract and subsequent formation of green phosphate/Mo (V) complex at acid $\mathrm{pH}$. It evaluates both water-soluble and fatsoluble antioxidants (total antioxidant capacity). The results indicate higher total antioxidant capacity (expressed as ascorbic acid equivalent) in the methanolic extract (Table 3) of Moringa oleifera.

Table 3:- Results show total antioxidant activity of various extracts of Moringa oleifera.

\begin{tabular}{|l|l|}
\hline EXTRACT & $\begin{array}{l}\text { TAC }(\boldsymbol{\mu g} \text { of } \\
\text { ascorbic acid } \\
\text { per mg of } \\
\text { extract) }\end{array}$ \\
\hline Water & $21.13 \pm 0.02$ \\
\hline Hydro alcohol & $29.72 \pm 0.01$ \\
\hline Methanol & $45.61 \pm 0.03$ \\
\hline
\end{tabular}

*Data is presented as the mean \pm standard deviation.

\section{DPPH radical scavenging activity:-}

The DPPH radical scavenging activity is determined based on the ability of DPPH (1, 1-diphenyl-2-picrylhydrazyl) a stable free radical, to decolorize in the presence of antioxidants. The DPPH radical contains an odd electron, which is responsible for absorbance at $517 \mathrm{~nm}$. When DPPH accepts an electron donated by an antioxidant compound, the DPPH is decolorized which can be quantitatively measured from the changes in absorbance. All of the assessed extracts of Moringa oleifera were able to reduce the stable, purple-colored radical DPPH to the yellow-colored DPPH-H form (Table 4). In the present study DPPH radical scavenging was higher in the methanolic extract of Moringa oleifera $\left(\mathrm{IC}_{50}: 160 \mu \mathrm{g} / \mathrm{ml}\right)$. The $\mathrm{IC}_{50}$ value of aqueous extract of Moringa oleifera was $400 \mu \mathrm{g} / \mathrm{ml}$ and that of hydro alcoholic extract was $420 \mu \mathrm{g} / \mathrm{ml}$.

Table 4: $\mathrm{IC}_{50}$ values $(\mu \mathrm{g} / \mathrm{ml})$ of the neutralization of DPPH radical with Moringa oleifera extracts.

\begin{tabular}{|l|l|}
\hline EXTRACT & $\mathbf{I C}_{\mathbf{5 0}}(\boldsymbol{\mu g} / \mathbf{m l})$ \\
\hline Water & 400 \\
\hline $\begin{array}{l}\text { Hydro } \\
\text { alcohol }\end{array}$ & 420 \\
\hline Methanol & 160 \\
\hline
\end{tabular}

\section{Reducing power:-}

Various concentrations (100-1000 $\mu \mathrm{l})$ of leaf extracts of Moringa oleifera were found to have significant reducing power. All the extracts exhibited a concentration dependent increase in reducing power. (Fig: 1). Methanolic extract of Moringa oleifera showed superior reducing activity. The reducing power of the extracts increased with increasing concentration, which suggests that the electron donating ability of the extracts is concentration dependent. 
Fig 1:-Reducing power of various extracts of Moringa oleifera.

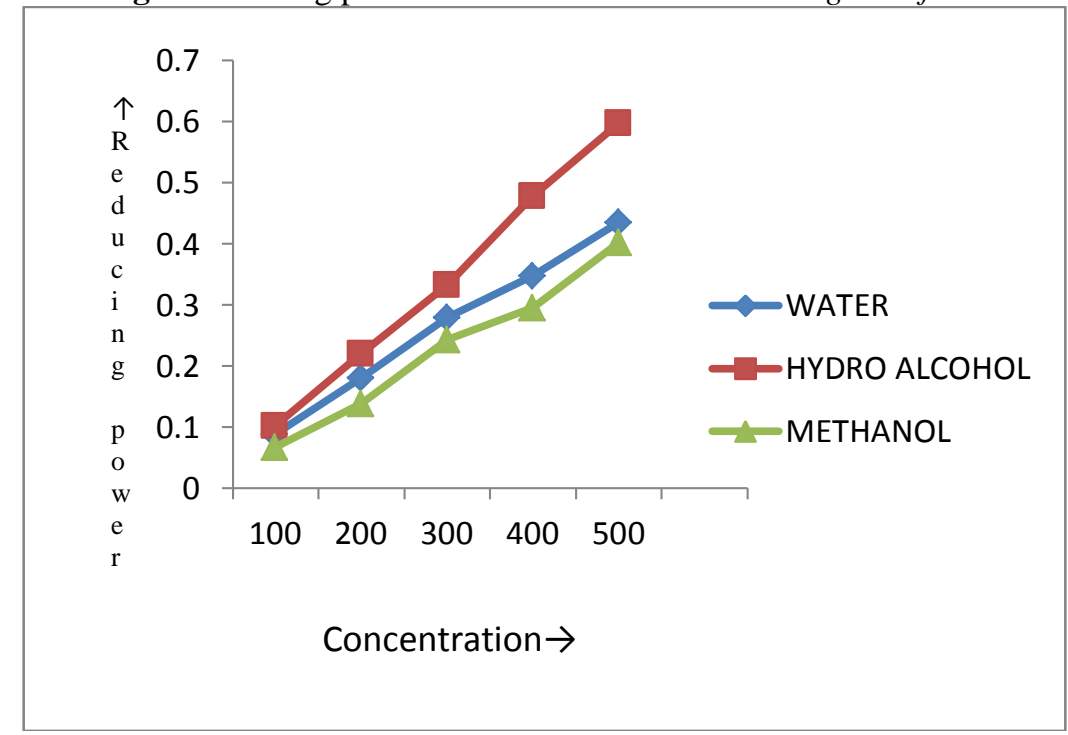

Nitric oxide radical scavenging activity:-

The methanolic extract of Moringa oleifera effectively reduced the generation of nitric oxide from sodium nitroprusside. Moringa oleifera methanolic extract showed nitric oxide scavenging activity at the concentration of $318 \mu \mathrm{g} / \mathrm{ml}\left(\mathrm{IC}_{50}\right)$ (Table 5). The result shows that methanol extract of Moringa oleifera is a superior nitric oxide radical scavenger. Water $\left(\mathrm{IC}_{50}: 1501 \mu \mathrm{g} / \mathrm{ml}\right.$ ) and hydroalcoholic ( $\mathrm{IC}_{50}: 1458 \mu \mathrm{g} / \mathrm{ml}$ ) extracts also shows a significant nitric oxide radical scavenging activity.

Table 5:-Nitric oxide radical scavenging acivity of $\left(\mathrm{IC}_{50}\right)$ Moringa oleifera extracts.

\begin{tabular}{|l|l|}
\hline EXTRACT & IC $_{\mathbf{5 0}}(\boldsymbol{\mu g} \mathbf{g} \mathbf{m l})$ \\
\hline Water & 1501 \\
\hline Hydro alcohol & 1458 \\
\hline Methanol & 318 \\
\hline
\end{tabular}

\section{Hydrogen peroxide scavenging activity:-}

The results showed all the extracts had potent $\mathrm{H}_{2} \mathrm{O}_{2}$ scavenging activity which may be due to the antioxidant compounds. As the antioxidant components present in the extracts are good electron donors, they may accelerate the conversion of $\mathrm{H}_{2} \mathrm{O}_{2}$ to $\mathrm{H}_{2} \mathrm{O}$. Methanolic extract $\left(\mathrm{IC}_{50}: 593 \mu \mathrm{g} / \mathrm{ml}\right)$ of Moringa oleifera exhibits greater scavenging activity compared to all other extracts (Table 6). The $\mathrm{IC}_{50}$ value of aqueous extract of Moringa oleifera was 868 $\mu \mathrm{g} / \mathrm{ml}$ and that of hydro alcoholic extract was $1101 \mu \mathrm{g} / \mathrm{ml}$.

Table 6:-Hydrogen peroxide scavenging activity of $\left(\mathrm{IC}_{50}\right)$ Moringa oleifera extracts.

\begin{tabular}{|l|l|}
\hline EXTRACT & IC $_{\mathbf{5 0}}(\boldsymbol{\mu g} / \mathbf{m l})$ \\
\hline Water & 868 \\
\hline Hydro alcohol & 1101 \\
\hline Methanol & 593 \\
\hline
\end{tabular}

Hydroxyl radical scavenging activity:-

In the present study the methanolic extract of Moringa oleifera showed potent hydroxyl radical scavenging activity. The $\mathrm{IC}_{50}$ value of methanolic extract of Moringa oleifera was $2063 \mu \mathrm{g} / \mathrm{ml}$ (Table 7). All the extracts showed a significant hydroxyl radical scavenging activity. The $\mathrm{IC}_{50}$ value of aqueous extract of Moringa oleifera was 3540 $\mu \mathrm{g} / \mathrm{ml}$ and that of hydro alcoholic extract was $2775 \mu \mathrm{g} / \mathrm{ml}$.

Table 7:-Hydroxyl radical scavenging activity $\left(\mathrm{IC}_{50}\right)$ of Moringa oleifera extracts.

\begin{tabular}{|l|l|}
\hline EXTRACT & IC $_{\mathbf{5 0}}(\boldsymbol{\mu g} / \mathbf{m l})$ \\
\hline Water & 3540 \\
\hline
\end{tabular}




\begin{tabular}{|l|l|}
\hline Hydro alcohol & 2775 \\
\hline Methanol & 2063 \\
\hline
\end{tabular}

\section{Superoxide radical scavenging activity:-}

The result of superoxide radical (SO) scavenging activity obtained for the extracts of Moringa oleifera showed dose dependent free radical scavenging activity and the percentage of inhibition was shown in [Table 8]. In the present study, methanolic extract of Moringa oleifera was found to be a superior scavenger of superoxide radicals $\left(\mathrm{IC}_{50}: 151\right.$ $\mu \mathrm{g} / \mathrm{ml})$. The $\mathrm{IC}_{50}$ value of aqueous extract of Moringa oleifera was $180 \mu \mathrm{g} / \mathrm{ml}$ and that of hydro alcoholic extract was $220 \mu \mathrm{g} / \mathrm{ml}$.

Table 8:-Superoxide anion $\left(\mathrm{O}_{2}\right.$--) radical-scavenging activity $\left(\mathrm{IC}_{50}\right)$ of Moringa oleifera extracts.

\begin{tabular}{|l|l|}
\hline Extract & $\mathbf{I C}_{\mathbf{5 0}}(\boldsymbol{\mu} \mathbf{g} / \mathbf{m l})$ \\
\hline Water & 180 \\
\hline Hydro alcohol & 220 \\
\hline Methanol & 151 \\
\hline
\end{tabular}

\section{Conclusion:-}

The present study evaluated the nutritional and antioxidant potential of leaves of the plant. The nutritional analysis revealed that Moringa oleifera is rich in carbohydrates, proteins, free amino acids and vitamins. Anti nutritional factors were found in very minute quantity. Moringa oleifera is rich in various mineral elements and could be utilized to treat a number of diseases that are mainly caused due to the deficiency of these minerals. Since the plant is rich in nutrients and anti nutrients were found in very minute quantity suggests their utility for consumption. Antioxidant assays confirmed the antioxidant potential of the plant. Methanolic extract of Moringa oleifera shows strong antioxidant activity than the other two extracts. The present study confirms the nutraceutical potential of the plant.

\section{Acknowledgement:-}

The financial assistance from DST/ INSPIRE, New Delhi, India and the facilities provided by University of Kerala are greatly acknowledged.

\section{References:-}

1. "Nutraceuticals / Functional Foods and Health Claims on Foods: Policy Paper". Health Canada. June 24, 2013. Retrieved January 30, 2014.

2. AOAC; 1990. Association of Official Analytical Chemists. Official methods of analysis, 15th edition. Washington DC

3. AOAC., 1994. Official method of analysis 15th Ed, Association of Official Analytical Chemist, Benjamin Franklion Station Washington D. C. U.S.A.vitamin A,C E,B.

4. Bligh, E.G.and Dyer, W.J.1959. A rapid method for total lipid extraction and purification.Can.J.Biochem.Physiol.37:911-917.

5. Fontana, M., Mosca, L., and Rosei M.A., 2001. Interaction of enkephalines with oxyradicals. Biochem. Pharmacol. 61: 1253-1257.

6. Halliwell B, Gutteridge JMC, Aruoma OI., 1987. The deoxyribose method: a simple "test tube" assay for determination of rate constants for reactions of hydroxyl radicals. Anal. Biochem; 165: 215-219.

7. Hodge, J.E, Hofreiter, B.T, 1962, Determination of reducing sugar and carbohydrate,Methods in carbohydrate chemistry;380-394.

8. Ilavarasan R., Mallika M. and Venkataraman S.,2005. Anti inflammatory and antioxidant activites of Linn bark extract. Afr. J. Trad, 2 (1): 70-85.

9. M.S. Blois., 1958. Antioxidant determination by the use of a stable free radical, Nature 181 1199-1200.Song.

10. Moore, S, \& Stein W,H.,1948. Photometric ninhydrin method for use in chromatography of amino acids, j'. biol. Cheiu. 176, 367.

11. Okwu DE and Josiah C., 2006. Evaluation of chemical composition of two Nigerian medicinal plants. African Journal of Biotechnology; 5(4):357-361. vitamin A,E,C,B.

12. Oyaizu M., 1986. Studies on products of browning reaction prepared from glycosamine. Japanese journal of nutrition. 44: 307-314. 
13. Prieto P, Pineda M, Aguilar M., 1999.Spectrophotometric quantitation of antioxidant capacity through the formation of a phosphomolybdenum complex: specific application to thedetermination of vitamin E. Anal Biochem; 269: 337-341.

14. RJ Ruch; SJ Cheng; JE Klaunig, Carcinogenesis.,1989, 10, 1003.

15. Sadasivam S, Manickam A.,1996. Biochemical methods. 2nd edition, New Age International (p) Ltd. Publisher, New Delhi, pp 179-186.

16. Schanderl SH., 1970. Methods in food analysis. Academic Press: New York: 70 tannin

17. Siddhuraju, P., Becker, K., 2003. Antioxidant properties of various solvent extracts of total phenolic constituents from three different agro-climatic origins of drumstick tree (MoringaoleiferaLam.. J. Agric. Food Chem., 15: 2144-2155.

18. Singh, K.K., Kumar, K., 1999. Ethnotherapeutics of some medicinal plants used as antipyretic agent among the tribals of India. J. Econ. Taxon. Bot., 23: 135-141.

19. The Wealth of India (A Dictionary of Indian Raw Materials and Industrial Products)., 1962. Raw Materials, Vol. VI: L-M; Council of Scientific and Industrial Research: New Delhi, 425-429. 